\title{
PENGARUH PEMBERIAN JUS KULIT DELIMA (PUNICA GRANATUM) TERHADAP KADAR KOLESTEROL TOTAL WANITA HIPERKOLESTEROLEMIA
}

\author{
Vito Andygian, Deny Yudi Fitranti ${ }^{*}$ \\ Program Studi Ilmu Gizi Fakultas Kedokteran Universitas Diponegoro \\ Jl.Dr.Sutomo No.18, Semarang, Telp (024) 8453708, Email : gizifk@ undip.ac.id
}

\begin{abstract}
Background : Hypercholesterolemia was one of risk factor for cardiovascular disease. Pomegranate peel contained anthocyanin which have beneficial effect to increase the HDL content so the free cholesterol inside body can be easily transported back to liver, and screted via bile acid. This study aimed to examine the effect of pomegranate peel intervention (Punica granatum) for total cholesterol content in hypercholesterolemic 30-49 years old women.

Methode : This was quasi experiment study designed with "pre-post control gorup" design. Subjects of the study were hypercholesteromic women with total cholesterol $\geq 200 \mathrm{mg} / \mathrm{dl}$, intervention group get $25 \mathrm{~g} /$ day of pomegranate peel juice and the control group get placebo. The intervention study conducted for 14 days. CHOD-PAP methode have been used for analyze the total cholesterol content. Blood sample retrieved after subject of the study had fasting for 10 hours long. Statistical analysis of pre and post cholesterol content in intervention group conducted by using dependent t-test, whereas the control group using non-paramteric test (wilcoxon test). Difference of postcholesterol content between intervention and control group analyzed by independent $t$-test, whereas the difference of pre-cholesterol content between intervention and control group analyzed by mann-whitney test. The double linear regression test were used for predict the effect of nutriotion intake toward cholesterol total content.

Result : Percentage of the hypercholesterolemic subject which were about 40-49 years old with overweight status was $27 \%$, and obesity status 33\%. Greater cholesterol intake was found in control group than intervention group. $25 \mathrm{~g} /$ day pomegranate peel juice treatment have significant effect for total cholesterol content $(p=0,013)$. The decreasing of the total cholesterol content mean after treatment in intervention and control group which are 6,83\% and 2,44\%. Intervention and control group of the study have no difference in total cholesterol decreasing $(p=0,182)$. The decreasing of total cholesterol level in intervention group influenced by 23,9\% cholesterol intake $(p=0,037)$.
\end{abstract}

Conclusion : The pomegranate peel juice treatment affect the total cholesterol content of the hypercholesterolemic 30-49 years old women. There were no total cholesterol content difference between intervention and control group.

Keywords : pomegranate peel juice; total cholesterol; hypercholesterolemia

\begin{abstract}
ABSTRAK
Latar Belakang : Hiperkolesterolemia merupakan salah satu faktor risiko terjadinya penyakit jantung dan pembuluh darah. Kulit delima mengandung anthocyanin yang dapat meningkatkan kadar HDL sehingga kolesterol bebas di dalam tubuh dapat dibawa kembali ke hati untuk dibuang melalui sekresi cairan empedu. Penelitian ini bertujuan untuk mengetahui perbedaan kadar kolesterol total setelah diberikan dan tidak diberikan jus kulit delima (Punica granatum) pada wanita usia 30-49 tahun yang mengalami hiperkolesterolemia.

Metode : Jenis penelitian adalah quasi experiment dengan rancangan pre-post control group design. Subjek adalah wanita hiperkolesterolemia dengan kadar kolesterol total $\geq 200 \mathrm{mg} / \mathrm{dl}$, kelompok intervensi mendapat $25 \mathrm{~g} / \mathrm{hari}$ jus kulit delima dan kelompok kontrol mendapat plasebo. Intervensi dilakukan selama 14 hari. Metode CHOD-PAP digunakan untuk menganalisis kadar kolesterol total sebelum dan setelah intervensi, darah diambil setelah subjek berpuasa selama 10 jam. Uji beda kadar kolesterol total sebelum dan setelah intervensi pada kelompok intervensi menggunakan uji dependent t-test dan uji beda kadar kolesterol total sebelum dan setelah intervensi pada kelompok kontrol menggunakan uji non parametrik wilcoxon. Perbedaan kadar kolesterol total setelah intervensi antara kelompok intervensi dan kontrol dan perbedaan penurunan kadar kolesterol total antara kelompok intervensi dan kontrol menggunakan uji independent t-test, sedangkan uji analisis perbedaan kadar kolesterol total sebelum intervensi antara kelompok intervensi dan kontrol menggunakan uji mann whitney. Uji regresi linier berganda dilakukan untuk memprediksi besar pengaruh asupan zat gizi terhadap kadar kolesterol total.

Hasil : Hiperkolesterolemia sebagian besar terdapat pada wanita usia 40-49 tahun dan status gizi overweight sebesar 27\% dan obesitas 33\%. Asupan kolesterol berlebih sebagian besar terdapat pada kelompok kontrol dibandingkan pada kelompok intervensi. Kadar kolesterol total sebelum dan setelah intervensi pada kelompok intervensi terdapat perbedaan $(p=0,013)$. Penurunan rerata kadar kolesterol total setelah intervensi pada kelompok intervensi dan kontrol yaitu 6,83\% dan 2,44\%. Perbedaan penurunan kadar kolesterol total antara kelompok intervensi dan kontrol tidak terdapat perbedaan $(p=0,182)$. Penurunan kadar kolesterol total pada kelompok intervensi dapat dipengaruhi oleh asupan kolesterol sebesar 23,9\% ( $p=0,037)$.
\end{abstract}

${ }^{*}$ Penulis Penanggungjawab 
Kesimpulan : Pemberian jus kulit delima berpengaruh terhadap penurunan kadar kolesterol total wanita usia 30 49 tahun yang mengalami hiperkolesterolemia. Selain itu, asupan kolesterol dapat mempengaruhi penurunan kadar kolesterol total. Perbedaan penurunan kadar kolesterol total antara kelompok intervensi dan kontrol tidak terdapat perbedaan.

Kata kunci : jus kulit delima; kolesterol total; hiperkolesterolemia

\section{PENDAHULUAN}

Hiperkolesterolemia merupakan kondisi akibat gangguan metabolisme lemak yang ditandai dengan tingginya kadar kolesterol total dalam darah. Pada kondisi tersebut apabila terjadi dalam jangka panjang menyebabkan terbentuknya gumpalan lemak dalam pembuluh darah sehingga dapat berisiko aterosklerosis. ${ }^{1}$ Aterosklerosis memiliki pengaruh terhadap timbulnya penyakit jantung dan pembuluh darah. Pada penyakit jantung dan pembuluh darah yang disebabkan aterosklerosis pembuluh darah mengalami penyempitan dan pengerasan. Hal ini menghambat aliran darah yang kaya oksigen menuju ke jantung. ${ }^{2,3}$ Berdasarkan Profil Kesehatan Provinsi Jawa Tengah tahun 2011 penyakit jantung dan pembuluh darah merupakan kasus tertinggi yaitu sebesar $62,43 \%$ dari total 1.409 .857 kasus penyakit tidak menular, ${ }^{7}$ sedangkan di Kota Semarang dilaporkan 303.485 kasus penyakit tidak menular dan $42,27 \%$ dari kasus tersebut merupakan penyakit jantung dan pembuluh darah. ${ }^{8}$

Peningkatan kadar kolesterol dipengaruhi oleh asupan karbohidrat, protein, lemak, serat dan kolesterol. Peningkatan kadar kolesterol tersebut dapat ditekan dengan pengaturan pola diit. Pengaturan pola diit untuk menurunkan kadar kolesterol dilakukan dengan mengontrol asupan zat gizi secara seimbang sesuai dengan kebutuhan. Asupan serat yang tinggi dapat menurunkan kadar kolesterol dengan cara meningkatkan pengeluaran cairan empedu. Selain itu bakteri di dalam usus memfermentasi serat untuk memproduksi asam asetat propionate, dan butirat yang berfungsi untuk menghambat sintesis kolesterol. ${ }^{10}$

Buah dan sayur merupakan asupan zat gizi yang tinggi kandungan serat. Selain itu, buah dan sayur juga mengandung antioksidan berupa flavonoid. ${ }^{11}$ Flavonoid merupakan zat aktif yang memiliki pengaruh terhadap kadar profil lipid dengan cara mengaktifkan sistem multi enzim seperti citocrome $P-450$ dan $b 5$ yang mempunyai fungsi mengikat kadar kolesterol dan cairan empedu untuk dieksresikan. Flavonoid terdiri dari 6 kelompok utama, yaitu chalone, flavon, flavonol, flavonon, anthocyanin dan isoflavonoids. Penelitian terdahulu menunjukan bahwa pemberian $160 \mathrm{mg}$ anthocyanin yang diberikan dua kali/hari selama 12 minggu pada 78 wanita dan 42 pria usia 40-65 tahun yang mengalami dislipidemia terbukti dapat menurunkan kadar kolesterol total sebesar $5,7 \mathrm{mg} / \mathrm{dl} .^{14}$

Buah delima (Punica granatum) memiliki kandungan flavonoid yang didominasi oleh anthocyanin. Tanaman delima ini memiliki manfaat, akan tetapi pada umumnya masyarakat hanya mengkonsumsi buahnya, sedangkan kulitnya tidak dikonsumsi. Kulit delima telah diteliti dan terbukti bahwa kulit delima kering mengandung anthocyanin 3 kali lebih tinggi dibandingkan pada bagian daging dan bijinya yaitu sebesar 51,02 \pm $10,33 \mathrm{mg} / \mathrm{g}$. ${ }^{15}$

Berdasarkan penelitian di Mesir yang dilakukan pada tikus dengan pemberian kulit delima dosis $250 \mathrm{mg} / \mathrm{kg}$ berat badan tikus selama 4 minggu dapat menurunkan kadar kolesterol total yaitu $26,49 \mathrm{mg} / \mathrm{dl} .{ }^{16}$ Penelitian yang juga dilakukan di Mesir terhadap tikus yang diberikan kulit delima dengan dosis yang berbeda, yaitu dosis 400 dan $800 \mathrm{mg} / \mathrm{kg}$ berat badan tikus selama 8 minggu mempunyai pengaruh terhadap penurunan kadar kolesterol total. Kadar kolesterol tikus yang diberikan dosis $400 \mathrm{mg} / \mathrm{kg}$ dapat menurukan kadar kolesterol total sebesar $117,72 \mathrm{mg} / \mathrm{dl}$ dan kadar kolesterol total turun sebesar $134,56 \mathrm{mg} / \mathrm{dl}$ pada pemberian dosis $800 \mathrm{mg} / \mathrm{kg} .{ }^{17}$ Jika menurut penelitian terdahulu yang menggunakan suplemen anthocyanin, maka penelitian ini menggunakan kulit delima segar dengan dosis $25 \mathrm{~g}$ per hari selama 14 hari. Dosis pemberian kulit delima didapat dari perbandingan berat kulit delima segar dan kering $25: 7 .^{14}$

Penelitian ini bertujuan untuk mengetahui pengaruh pemberian jus kulit delima (Punica granatum) terhadap kadar kolesterol total wanita hiperkolesterolemia. Pada penelitian di Thailand menunjukan bahwa wanita yang mengalami hiperkolesterolemia didominasi pada kelompok usia 30-49 tahun. ${ }^{18}$ Buah delima merah dalam penelitian ini dipilih sebagai bahan intervensi karena kandungan anthocyanin pada buah delima merah lebih besar dari buah lainnya seperti buah apel merah, anggur merah dan strawberry. Kandungan anthocyanin pada buah delima merah sebesar $17 \mathrm{mg} / \mathrm{gram}$, apel merah sebesar 0,12 
$\mathrm{mg} / \mathrm{gram}$, anggur merah sebesar $0,26 \mathrm{mg} / \mathrm{gram}$ dan strawberry sebesar $0,21 \mathrm{mg} / \mathrm{gram} .{ }^{15,19}$

\section{METODE}

Penelitian dilakuan pada bulan September 2013 di Kantor Dinas Perhubungan, Komunikasi dan Informatika (DINHUBKOMINFO) Provinsi Jawa Tengah, Kota Semarang. Penelitian ini termasuk dalam ruang lingkup gizi medik dan merupakan penelitian quasi experiment dengan rancangan pre-post control group design. Penelitian yang bersifat eksperimental dapat dilaksanakan setelah mendapatkan persetujuan berupa Ethical Clearance dari Komisi Etik Fakultas Kedokteran Universitas Diponegoro. Populasi terjangkau dalam penelitian ini adalah wanita usia 30-49 tahun yang mengalami hiperkolesterolemia. Kriteria inklusi penelitian ini adalah wanita usia 30-49 tahun, memiliki kadar kolesterol total $\geq 200 \mathrm{mg} / \mathrm{dl}$, bersedia mengisi informed consent, tidak sedang mengonsumsi obat dan suplemen antihiperlipidemia selama penelitian, tidak dalam keadaan sakit atau dalam perawatan dokter berkaitan dengan penyakit jantung koroner, hipertensi, stroke, dislipidemia, dan penyakit kronik lainnya, tidak sedang hamil atau menyusui.

Berdasarkan perhitungan besar sampel dengan menggunakan rumus besar sampel untuk studi uji hipotesis terhadap rerata dua populasi independen, jumlah sampel minimal yang diperlukan sebesar 12 orang/kelompok ditambah $10 \%$ menjadi 13 orang/kelompok. Pada penelitian ini saat pengambilan data awal terdapat 46 orang yang telah bersedia mengisi informed consent, kemudian diambil darah untuk diperiksa kadar kolesterol total oleh pihak laboratorium. Subjek dari pengambilan data awal terpilih 30 orang yang telah memenuhi kriteria inklusi. Metode simple random sampling digunakan untuk membagi kelompok intervensi dan kontrol. Masing-masing kelompok terdiri dari 15 orang.

Variabel bebas dalam penelitian ini adalah pemberian jus kulit delima. Variabel terikat adalah kadar kolesterol total. Variabel perancu adalah asupan karbohidrat, protein, lemak, serat dan kolesterol. Kulit delima yang digunakan dari buah delima merah. Satuan kulit delima yang diberikan menggunakan gram. Jus kulit delima diberikan pada kelompok intervensi dengan kulit delima dosis 25 gram/orang/hari selama 14 hari, ditambahkan air $200 \mathrm{cc}$ dan sirup bebas gula 3 sendok, kemudian diblender sampai halus. Hasil setelah diblender terdapat endapan yang selanjutnya disaring dan endapan tidak diberikan pada saat intervensi. Kelompok kontrol diberikan plasebo selama 14 hari berupa sirup bebas gula 1 sendok. Data kadar kolesterol total diambil oleh pihak laboratorium dengan metode Cholesterol Oxidase Phenol Amino Phenazone (CHOD-PAP) melalui pembuluh darah vena setelah subjek penelitian berpuasa $10 \mathrm{jam}$. Kadar kolesterol total menggunakan satuan $\mathrm{mg} / \mathrm{dl}$. Data asupan zat gizi yang meliputi asupan energi, protein, lemak, karbohidrat, serat dan kolesterol diperoleh dari konsumsi makanan, minuman, dan suplemen subjek penelitian melalui wawancara selama intervensi menggunakan formulir food recall 24 jam. Satuan yang digunakan dalam food recall untuk asupan energi kalori (kkal), asupan protein, lemak, karbohidrat, dan serat gram (g), dan satuan asupan kolesterol milligram (mg). Perhitungan asupan energi, protein, lemak, karbohidrat, serat dan kolesterol menggunakan nutrisurvey.

Uji normalitas usia, Indeks Massa Tubuh (IMT), presentase asupan zat gizi (energi, protein, lemak dan karbohidrat), rerata asupan zat gizi (serat dan kolesterol), kadar kolesterol total sebelum dan setelah intervensi, penurunan kadar kolesterol total menggunakan uji shapiro-wilk. Uji beda kadar kolesterol total sebelum dan setelah intervensi pada kelompok intervensi menggunakan uji dependent t-test dan uji beda kadar kolesterol total sebelum dan setelah intervensi pada kelompok kontrol menggunakan uji non parametrik wilcoxon. Perbedaan antara kelompok intervensi dan kontrol untuk usia, IMT, persentase asupan (energi, protein dan karbohidrat), kadar kolesterol total setelah intervensi dan penurunan kadar kolesterol total menggunakan uji independent t-test, sedangkan uji beda untuk persentase asupan zat gizi (lemak), rerata asupan zat gizi (serat dan kolesterol) dan kadar kolesterol total sebelum intervensi menggunakan uji mann whitney. Uji regresi linier berganda dilakukan untuk memprediksi besar pengaruh asupan zat gizi terhadap kadar kolesterol total.

\section{HASIL PENELITIAN \\ Karakteristik Subjek}

Penelitian ini melibatkan 30 wanita usia 30-49 tahun yang mengalami hiperkolesterolemia sebagai subjek penelitian. Karakteristik subjek yang terdiri dari gambaran umur dan status gizi disajikan pada Tabel 1 dan 2 . 
Tabel 1. Perbedaan usia dan status gizi kelompok intervensi dan kontrol

\begin{tabular}{lccc}
\hline \multicolumn{1}{c}{ Variabel } & $\begin{array}{c}\text { Intervensi } \\
(\mathbf{n = 1 5}) \\
\text { Rerata } \pm \text { SD }\end{array}$ & $\begin{array}{c}\text { Kontrol } \\
(\mathbf{n = 1 5}) \\
\text { Rerata } \pm \text { SD }\end{array}$ & p \\
\hline Umur (tahun) & $43,09 \pm 4,77$ & $40,01 \pm 5,52$ & $0,114^{\mathrm{a}}$ \\
IMT $\left(\mathrm{kg} / \mathrm{m}^{2}\right)$ & $24,91 \pm 4,42$ & $24,2 \pm 3,70$ & $0,641^{\mathrm{a}}$ \\
\hline
\end{tabular}

${ }^{\mathrm{a}} \mathrm{Uji}$ Independent $t$-test

Pada Tabel 1 menjelaskan bahwa rerata umur kelompok intevensi adalah 43 tahun dan kelompok kontrol 40 tahun. Hasil analisis pada

kelompok intervensi dan kontrol tidak terdapat perbedaan usia dan IMT $(\mathrm{p}>0,05)$.

Tabel 2. Gambaran usia dan status gizi kelompok intervensi dan kontrol

\begin{tabular}{|c|c|c|c|c|c|c|}
\hline \multirow[t]{2}{*}{ Variabel } & \multicolumn{2}{|c|}{$\begin{array}{c}\text { Intervensi } \\
(n=15)\end{array}$} & \multicolumn{2}{|c|}{$\begin{array}{c}\text { Kontro } \\
1 \\
(\mathrm{n}=15)\end{array}$} & \multicolumn{2}{|c|}{$\begin{array}{c}\text { Total } \\
(\mathbf{n}=\mathbf{3 0})\end{array}$} \\
\hline & $\mathbf{n}$ & $\%$ & $\mathbf{n}$ & $\%$ & $\mathbf{n}$ & $\%$ \\
\hline Umur (tahun) & & & & & & \\
\hline $30-39$ & 4 & $27 \%$ & 7 & $\begin{array}{l}47 \\
\%\end{array}$ & 11 & $37 \%$ \\
\hline $40-49$ & 11 & $73 \%$ & 8 & $\begin{array}{l}53 \\
\%\end{array}$ & 19 & $63 \%$ \\
\hline Status Gizi & & & & & & \\
\hline Normal & 6 & $40 \%$ & 6 & $\begin{array}{l}40 \\
\%\end{array}$ & 12 & $40 \%$ \\
\hline Overweight & 4 & $27 \%$ & 4 & $\begin{array}{l}27 \\
\%\end{array}$ & 8 & $27 \%$ \\
\hline Obesitas & 5 & $33 \%$ & 5 & $\begin{array}{l}33 \\
\%\end{array}$ & 10 & $33 \%$ \\
\hline
\end{tabular}

Pada Tabel 2 menyebutkan bahwa penelitian ini sebagian besar diikuti subjek berumur 40-49 tahun. Status gizi subjek berdasarkan IMT pada kedua kelompok terdapat $27 \%$ overweight dan obesitas $33 \%$.

Asupan zat gizi selama intervensi
Perbedaan asupan zat gizi subjek yang diperoleh dari makanan, minuman, dan suplemen meliputi asupan energi, protein, lemak, karbohidrat, serat, dan kolesterol. Data tersebut disajikan dalam bentuk persentase tingkat kecukupan. (Tabel 3 dan 4)

Tabel 3. Persentase asupan energi, protein, lemak, karbohidrat, asupan serat dan kolesterol kelompok intervensi dan kontrol selama intervensi

\begin{tabular}{|c|c|c|c|c|c|c|c|}
\hline \multirow{2}{*}{$\begin{array}{l}\text { Asupan zat gizi } \\
\text { selama intervensi }\end{array}$} & \multicolumn{2}{|c|}{ Nilai } & \multirow{2}{*}{$\begin{array}{c}\text { Intervensi } \\
(\mathbf{n}=15)\end{array}$} & \multicolumn{2}{|c|}{ Nilai } & \multirow{2}{*}{$\begin{array}{c}\text { Kontrol } \\
(n=15)\end{array}$} & \multirow[b]{2}{*}{$\mathbf{p}$} \\
\hline & Min & Maks & & Min & Maks & & \\
\hline \multicolumn{8}{|l|}{ Tingkat kecukupan (\%) } \\
\hline Energi & 54,23 & 75,05 & $68,73 \pm 6,15^{1}$ & 51,33 & 96,09 & $67,776 \pm 11,42^{1}$ & $0,775^{\mathrm{a}}$ \\
\hline Protein & 52,63 & 74,77 & $67,19 \pm 6,06^{1}$ & 46,28 & 89,26 & $69,55 \pm 11,83^{1}$ & $0,497^{\mathrm{a}}$ \\
\hline Lemak & 71,41 & 103,02 & $84,94 \pm 9,75^{2}$ & 55 & 151,95 & $82,94 \pm 22,92^{2}$ & $0,820^{\mathrm{b}}$ \\
\hline Karbohidrat & 45,09 & 76,57 & $62,51 \pm 8,36^{1}$ & 46,46 & 75,93 & $58,29 \pm 8,05^{1}$ & $0,170^{\mathrm{a}}$ \\
\hline \multicolumn{8}{|l|}{ Asupan } \\
\hline Serat (g) & 5,01 & 9,04 & $6,96 \pm 1,34^{2}$ & 5,84 & 14,7 & $7,49 \pm 2,2^{2}$ & $0,165^{\mathrm{b}}$ \\
\hline Kolesterol (mg) & 95,22 & 428,79 & $207,55 \pm 76,4^{2}$ & 128,57 & 260,52 & $212,66 \pm 40,50^{2}$ & $0,682^{b}$ \\
\hline
\end{tabular}

${ }^{1}$ Rerata \pm SD,${ }^{2}$ Median \pm SD

${ }^{\mathrm{a}} \mathrm{Uji}$ Independent $t$-test, ${ }^{\mathrm{b}}$ Mann-Whitney 
Pada Tabel 3 menjelaskan bahwa rerata tingkat kecukupan dan asupan zat gizi subjek pada kelompok intervensi dan kontrol tidak terdapat perbedaan $(\mathrm{p}>0,05)$.

Tabel 4. Kecukupan asupan zat gizi kelompok intervensi dan kontrol

\begin{tabular}{|c|c|c|c|c|c|c|}
\hline \multirow[t]{2}{*}{$\begin{array}{c}\text { Asupan zat gizi } \\
\text { selama intervensi }\end{array}$} & \multicolumn{2}{|c|}{$\begin{array}{c}\text { Intervensi } \\
(\mathbf{n}=\mathbf{1 5})\end{array}$} & \multicolumn{2}{|c|}{$\begin{array}{c}\text { Kontrol } \\
(n=15)\end{array}$} & \multicolumn{2}{|c|}{ Total $(n=30)$} \\
\hline & $\mathbf{n}$ & $\%$ & $\mathbf{n}$ & $\%$ & $\mathbf{n}$ & $\%$ \\
\hline \multicolumn{7}{|l|}{ Energi } \\
\hline$>100 \%$ (berlebih) & 0 & 0 & 0 & 0 & 0 & 0 \\
\hline$\leq 100 \%$ (baik) & 15 & 100 & 15 & 100 & 30 & 100 \\
\hline \multicolumn{7}{|l|}{ Protein } \\
\hline$>100 \%$ (berlebih) & 0 & 0 & 0 & 0 & 0 & 0 \\
\hline$\leq 100 \%$ (baik) & 15 & 100 & 15 & 100 & 30 & 90 \\
\hline \multicolumn{7}{|l|}{ Lemak } \\
\hline$>100 \%$ (berlebih) & 2 & 13,33 & 2 & 13,33 & 4 & 13,33 \\
\hline$\leq 100 \%$ (baik) & 13 & 86,67 & 13 & 86,67 & 26 & 86,67 \\
\hline \multicolumn{7}{|l|}{ Karbohidrat } \\
\hline$>100 \%$ (berlebih) & 0 & 0 & 0 & 0 & 0 & 0 \\
\hline$\leq 100 \%$ (baik) & 15 & 100 & 15 & 100 & 30 & 100 \\
\hline \multicolumn{7}{|l|}{ Serat } \\
\hline$\geq 25$ gram (baik) & 0 & 0 & 0 & 0 & 0 & 0 \\
\hline $\begin{array}{l}<25 \text { gram } \\
\text { (kurang) }\end{array}$ & 15 & 100 & 15 & 100 & 30 & 100 \\
\hline \multicolumn{7}{|l|}{ Kolesterol } \\
\hline >200 (berlebih) & 8 & 53,33 & 10 & 66,67 & 18 & 60 \\
\hline$\leq 200$ (baik) & 7 & 46,67 & 5 & 33,33 & 12 & 40 \\
\hline
\end{tabular}

Pada Tabel 4 menyebutkan bahwa asupan energi kelompok intervensi dan kontrol dalam kategori baik, Asupan protein kelompok intervensi dan kontrol dalam kategori baik, Asupan lemak kelompok intervensi dan kontrol sebagian besar dalam kategori baik, Asupan karbohidrat kelompok intervensi dan kontrol dalam kategori baik, Asupan serat kelompok intervensi dan kontrol dalam kategori kurang, asupan kolesterol kelompok intervensi dan kontrol sebagian besar dalam kategori berlebih.

\section{Kadar kolesterol total sebelum dan setelah intervensi}

Perbedaan kadar kolesterol total pada kelompok intervensi dan kontrol meliputi kadar kolesterol total sebelum dan setelah intervensi, dan perbedaan penurunan. Data tersebut disajikan dalam bentuk rerata. (Tabel 5)

Tabel 5. Perbedaan kadar kolesterol total sebelum dan setelah intervensi

\begin{tabular}{|c|c|c|c|}
\hline \multirow[t]{2}{*}{ Variabel } & $\begin{array}{c}\text { Intervensi } \\
(n=15)\end{array}$ & Kontrol $(n=15)$ & \multirow[t]{2}{*}{$\mathbf{p}$} \\
\hline & Rerata \pm SD & Rerata \pm SD & \\
\hline \multicolumn{4}{|l|}{ Kolesterol total (mg/dl) } \\
\hline $\begin{array}{l}\text { Sebelum } \\
\text { intervensi }\end{array}$ & $264,67 \pm 35,82$ & $224,13 \pm 31,98$ & $0,001^{\mathrm{c}}$ \\
\hline Setelah intervensi & $246,60 \pm 27,49$ & $218,67 \pm 30,94$ & $0,014^{\mathrm{d}}$ \\
\hline $\begin{array}{l}\text { Penurunan } \\
\text { Pents }\end{array}$ & $18,07 \pm 24,63$ & $5,46 \pm 25,80$ & $0,182^{\mathrm{d}}$ \\
\hline $\mathrm{p}$ & $0,013^{\mathrm{a}}$ & $0,378^{\mathrm{b}}$ & \\
\hline
\end{tabular}

Pada Tabel 5 menyebutkan bahwa terdapat perbedaan kadar kolesterol total pada kedua kelompok baik sebelum maupun setelah intervensi. Pada penelitian kelompok intervensi, rerata kadar kolesterol total sebelum dan setelah intervensi terdapat perbedaan $(\mathrm{p}<0,05)$, sedangkan pada kelompok kontrol tidak terdapat perbedaan rerata kadar kolesterol total sebelum dan setelah 
intervensi ( $p>0,05)$. Kadar kolesterol total pada kelompok intervensi dan kontrol mengalami penurunan. Rerata penurunan kadar kolesterol total pada kelompok intervensi sebesar $18,07 \pm 24,63$ $\mathrm{mg} / \mathrm{dl}$ dan kelompok kontrol sebesar 5,46 $\pm 25,80$ $\mathrm{mg} / \mathrm{dl}$. Rerata penurunan kadar kolesterol total antara kelompok intervensi dan kontrol tidak terdapat perbedaan $(\mathrm{p}>0,05)$.

Pengaruh variabel perancu terhadap variasi kadar kolesterol total sebelum dan setelah intervensi pada kelompok intervensi
Variabel perancu dalam penelitian ini adalah asupan energi, protein, lemak, karbohidrat, serat dan kolesterol. Variabel yang mempunyai korelasi <0,25 akan diuji regresi linier berganda. Pada kelompok intervensi, variasi kadar kolesterol total dapat dipengaruhi oleh variasi asupan kolesterol $(\mathrm{p}<0,05)$. Angka adjusted $R$ square adalah 0,239 menunjukan bahwa 23,9\% variasi kadar kolesterol total dapat disebabkan oleh variasi asupan kolesterol. (Tabel 6)

Tabel 6. Pengaruh variabel perancu terhadap variasi kadar koleserol total sebelum dan setelah intervensi pada kelompok intervensi

\begin{tabular}{lccc}
\hline Variabel & Koefisien & $\begin{array}{c}\text { Adjusted } \boldsymbol{R} \\
\text { square }\end{array}$ & $\mathbf{p}$ \\
\hline Asupan kolesterol & $-0,175$ & 0,239 & $0,037^{1}$ \\
Constant & 54,395 & 0,239 & $0,006^{1}$ \\
\hline
\end{tabular}

${ }^{1}$ Uji regresi linier berganda

\section{PEMBAHASAN}

Hiperkolesterolemia yang terjadi pada wanita usia 30-49 tahun ditandai dengan peningkatan kadar kolesterol total $\geq 200 \mathrm{mg} / \mathrm{dl}$. Peningkatan kadar kolesterol total dapat disebabkan pola diit yang tidak baik seperti asupan kolesterol tinggi dan asupan serat rendah. Pengaturan pola diit dapat menurunkan kadar kolesterol dengan cara mengontrol asupan zat gizi secara seimbang sesuai dengan kebutuhan yang berpedoman pada Angka Kecukupan Gizi (AKG) untuk asupan energi, protein, lemak, kabohidrat, American Dietetic Association (ADA) untuk asupan serat dan National Cholesterol Education Program (NECP) untuk asupan kolesterol. Asupan serat yang tinggi dapat menurunkan kadar kolesterol dengan cara meningkatkan pengeluaran cairan empedu lalu disekresikan bersama feses..$^{10,20-}$ ${ }^{22}$ Buah dan sayur merupakan sumber makanan kaya akan asupan serat. Selain serat, buah dan sayur juga mengandung antioksidan berupa flavonoid. Flavonoid dapat mengaktifkan sistem multi enzim seperti citrome $P-450$ dan b5 yang berfungsi mengikat kolesterol dan cairan empedu untuk disekresikan. Flavonoid terdiri dari beberapa kelompok salah satunya anthocyanin. Kandungan anthocyanin yang tinggi dapat ditemukan pada kulit delima. Jus kulit delima dan plasebo pada penelitian ini digunakan sebagai bahan intervensi. Jus kulit delima diberikan pada kelompok intervensi dan plasebo diberikan pada kelompok kontrol. Pada tiap kelompok terdiri dari 15 wanita usia 30-49 tahun yang mengalami hiperkolesterolemia. ${ }^{11}$

Wanita usia 30-49 tahun diketahui belum mengalami menopause dan tergolong wanita usia subur. Pada usia tersebut hormon estrogen masih berfungsi dengan baik sebagai kardioprotektif atau mencegah terbentuknya plak di pembuluh darah arteri dengan meningkatkan kadar kolesterol High Density Lipoprotein (HDL) dan menurunkan kadar kolesterol Low Density Lipoprotein (LDL), dan memiliki efek antioksidan yang berpengaruh terhadap kolesterol total. Hiperkolesterolemia yang terjadi pada wanita usia 30-49 tahun sebagian besar dialami pada kelompok usai 40-49 tahun. $^{23}$

Pada penelitian ini sebagian besar memiliki status gizi overweight sebesar $27 \%$ dan obesitas 33\%. Status gizi overweight dan obesitas memiliki risiko terjadinya penyakit jantung koroner lebih besar dibandingkan dengan status gizi underweight dan normal. Penderita obesitas terdapat kelainan hormon leptin yang dapat menggangu dalam mengontrol nafsu makan dan berdampak pada penyimpanan lemak dalam tubuh terganggu sehingga menimbulkan gangguan metabolisme lipoprotein yang ditandai dengan kadar trigliserida dan ester kolesterol meningkat. ${ }^{24,25}$ Peningkatan trigliserida yang besar dalam sirkulasi darah menyebabkan kadar kolesterol yang dibawa oleh Very Low Density Lipoprotein (VLDL) dan LDL meningkat, hal ini dapat terjadi penumpukan lemak berlebihan didalam tubuh dan meningkatkan kadar kolesterol total. ${ }^{26}$ 
Asupan zat gizi selama penelitian baik wanita yang diberikan jus kulit delima maupun wanita yang diberikan plasebo tidak terdapat perbedaan. Asupan zat gizi yang tidak terdapat perbedaan meliputi asupan energi, protein, lemak, karbohidrat, serat dan kolesterol. Asupan energi, protein, lemak, karbohidrat, serat pada wanita yang diberikan jus kulit delima dan wanita yang diberikan plasebo dalam kategori baik, sedangkan asupan kolesterol dalam kategori berlebihan, hal tersebut dapat disebabkan wanita yang diberikan jus kulit delima dan wanita yang diberikan plasebo membatasi asupan makanan (energi, protein, lemak, karbohidrat dan serat dalam kategori baik) tanpa disertai kualitas makanan (kolesterol dalam kategori berlebih) yang dikonsumsi selama pemberian kulit delima dan plasebo. Pembatasan asupan tersebut dilakukan setelah wanita yang diberikan kulit delima dan plasebo mengetahui bahwa kadar kolesterol total sebelum pemberian jus kulit delima dan plasebo dalam kategori tinggi.

Kadar kolesterol total sebelum diberikan jus kulit delima dan plasebo antara wanita yang diberikan jus kulit delima dan wanita yang diberikan plasebo terdapat perbedaan $(\mathrm{p}=0,001)$ sehingga kadar kolesterol total setelah diberikan jus kulit delima dan plasebo antara wanita yang diberikan jus kulit delima dan wanita yang diberikan plasebo juga terdapat perbedaan ( $\mathrm{p}=0,014)$. Wanita yang diberikan jus kulit delima, kadar kolesterol total sebelum dan setelah diberikan jus kulit delima terdapat penurunan bermakna sebesar $18,07 \mathrm{mg} / \mathrm{dl}$ atau $6,83 \%$ $(\mathrm{p}=0,013)$ karena kulit delima dosis 25 gram/orang/hari selama 14 hari mengandung anthocyanin dimana 1 gram kulit delima kering mengandung anthocyanin sebesar 51,02 mg dan serat sebesar 0,7 gram. ${ }^{15,27}$ Mekanisme penurunan kolesterol total oleh anthocyanin dapat dijelaskan sebagai berikut, anthocyanin diketahui dapat menghambat enzim Cholesteryl Ester Transfer Protein (CETP) dalam proses katabolisme HDL sehingga kadar HDL dalam darah dapat meningkat. Peningkatan kadar HDL dapat mempengaruhi kadar kolesterol dalam darah, HDL berfungsi sebagai pengangkut kolesterol bebas dalam darah yang dibawa kembali ke hati dan selanjutnya dibuang lewat sekresi cairan empedu. ${ }^{28,29}$

Penurunan kadar kolesterol total wanita yang diberikan jus kulit delima dapat disebabkan dari asupan zat gizi wanita tersebut. Berdasarkan asupan serat pada wanita yang diberikan jus kulit delima lebih besar dibandingkan asupan serat pada wanita yang diberikan plasebo karena asupan serat wanita yang diberikan jus kulit delima juga didapatkan dari jus kulit delima sehingga besar kecilnya asupan serat dapat mempengaruhi besar kecilnya penurunan kadar kolesterol total pada wanita yang diberikan jus kulit delima dan plasebo. Mekanisme serat larut air dalam menurunkan kadar kolesterol, yaitu dengan meningkatkan pengeluaran cairan empedu, cairan empedu yang telah terikat oleh serat tidak dapat direabsorpsi dan diresirkulasi melalui siklus enterohepatik. Di usus serat akan difermentasi bakteri untuk memproduksi asam asetat propionate dan butirat yang berfungsi untuk menghambat sintesis kolesterol, akibatnya cairan empedu ini akan terus ke usus besar untuk disekresikan bersama feses. ${ }^{30,31}$ Penelitian yang dilakukan di Indonesia menggunakan nata de coco dengan kandungan serat 4,8 gram dan 9,6 gram selama 14 hari pada wanita hiperkolesterolemia mampu menurunkan kadar kolesterol total sebesar $13,89 \mathrm{mg} / \mathrm{dl}$ dan $15,50 \mathrm{mg} / \mathrm{dl}^{32}$

Pada penelitian terdahulu menunjukan bahwa pemberian $160 \mathrm{mg}$ anthocyanin yang diberikan dua kali/hari selama 12 minggu pada wanita dislipidemia usia 40-65 tahun terbukti dapat menurunkan kadar kolesterol total sebesar 5,7 $\mathrm{mg} / \mathrm{dl} .{ }^{14}$ Penelitian lain yang dilakukan di Taiwan terhadap kadar kolesterol total laki-laki dan wanita usia 18-75 tahun dengan pemberian kapsul yang berisi ekstrak bunga Rosella (Hibiscus sabdariffa) $500 \mathrm{mg}$, tiap kapsul terdapat anthocyanin sebesar 20,1 mg. Pada penelitian tesebut dibagi dalam 3 kelompok, kelompok pertama diberi 1 kapsul/orang/hari atau $500 \mathrm{mg}$ ekstrak bunga Rosella, kelompok kedua diberi kapsul 2 kapsul/orang/hari atau $1000 \mathrm{mg}$ ekstrak bunga Rosella, kelompok ketiga diberi 3 kapsul/orang/hari atau $1500 \mathrm{mg}$ ekstrak bunga Rosella, kapsul tersebut diberikan selama 4 minggu dengan penurunan kadar kolesterol total sebesar 7,3 mg/dl pada kelompok pertama, 9,5 $\mathrm{mg} / \mathrm{dl}$ pada kelompok kedua, sedangkan pada kelompok ketiga terdapat peningkatan kadar kolesterol total sebesar $5,1 \mathrm{mg} / \mathrm{dl} .^{33}$

Hasil uji regresi linier berganda diketahui bahwa asupan kolesterol pada wanita yang diberikan jus kulit delima mempunyai pengaruh terhadap penurunan kadar kolesterol total. Berdasarkan tingkat kecukupan asupan kolesterol dalam kategori baik lebih besar terdapat pada wanita yang diberikan jus kulit delima dibandingkan wanita yang diberikan plasebo sehingga penurunan kadar kolesterol total yang terjadi pada wanita yang diberikan jus kulit delima 
23,9\% dapat disebabkan asupan kolesterol. Asupan kolesterol dalam kategori baik lebih besar terdapat pada wanita yang diberikan jus kulit delima dibandingkan wanita yang diberikan plasebo sehingga penurunan kadar kolesterol total pada wanita yang diberikan jus kulit delima lebih besar dibandingkan kadar kolesterol total wanita yang diberikan plasebo. Rata-rata peningkatan asupan kolesterol $100 \mathrm{mg} /$ hari dapat meningkatkan serum kolesterol 2-3 mg/dl. ${ }^{1}$

Wanita yang diberikan plasebo kadar kolesterol total sebelum dan setelah diberikan plasebo terdapat penurunan tetapi tidak bermakna $5,46 \mathrm{mg} / \mathrm{dl}$ atau $2,44 \%(\mathrm{p}=0,378)$. Penurunan kadar kolesterol total wanita yang diberikan plasebo seharusnya tidak mengalami penurunan karena plasebo yang diberikan berupa sirup bebas gula yang diketahui sirup bebas gula tersebut merupakan golongan gula alkohol jenis sorbitol dimana sorbitol tidak memiliki pengaruh terhadap kadar kolesterol total. Penurunan kadar kolesterol total antara wanita yang diberikan kulit delima dan wanita yang diberikan plasebo tidak terdapat perbedaan $(\mathrm{p}=0,182)$ karena asupan anthocyanin pada wanita yang diberikan plasebo tidak dianalisis, diketahui kandungan anthocyanin dapat menurunkan kadar kolesterol total. ${ }^{14}$

\section{KESIMPULAN}

Wanita usia 30-49 tahun yang mengalami hiperkolesterolemia diberikan jus kulit delima dengan kulit delima dosis 25 gram/orang/hari selama 14 hari terbukti kadar kolesterol total menurun sebesar $6,83 \%$. Selain itu, asupan kolesterol wanita yang diberikan jus kulit delima dapat mempengaruhi penurunan kadar kolesterol total sebesar $23,9 \%$. Perbedaan penurunan kadar kolesterol wanita yang diberikan kulit delima dan wanita yang diberikan plasebo tidak terdapat perbedaan.

\section{DAFTAR PUSTAKA}

1. Debra AK. Medical nutrition therapy in cardiovascular disease. In: Mahan LK, EscottStump S, Editors. Krause's food nutrition and diet therapy. $12^{\text {th }}$ Ed. USA: Saunders; 2008. p. 838-50.

2. Krummel DA. Medical Nutrition Therapy for Cardiovascular Disease. In : L. Kathleen Mahan, Sylvia Escott-Stump, editors. Krause's Food and Nutrition Therapy. $12^{\text {th }}$ edition. Philadelphia, USA - Saunders Elsevier; 2008.p.833;61

3. John D, Brunzell MD. Hypertriglyceridemia. The new England journal of medicine [serial online] 2007 [cited 2013 April 20]; 357.p.1009-17. Available from:
http://www.nejm.org/doi/full/10.1056/NEJMcp070 $\underline{061}$

4. Colin DM, Ties B, Dorma MF. Global and regional causes of death. British Medical Bulletin. [serial online] 2009; 92.p.7-32. [cited 2013 April 27] Available from: URL: http://bmb.oxfordjournals.org

5. Keputusan Menteri Kesehatan Republik Indonesia Nomor 854/Menkes/SK/IX/2009 tentang pedoman pengendalian penyakit jantung dan pembuluh darah. [serial online] [cited 2013 April 17] Available from: URL: www.hukor.depkes.go.id

6. World Health Statistics 2012. World Health Organization [serial online] [cited 2013 April 4] Available from: URL:

http://www.who.int/gho/publications/world health statistics/EN_WHS2012_Full.pdf

7. Profil Kesehatan Provinsi Jawa Tengah 2011 [serial online] [cited 2013 April 18] Available from: URL: http://jateng.bps.go.id/index.php

8. Profil Kesehatan Kota Semarang. Laporan Kematian Akibat Penyakit Tidak Menular. 2011.p.58-59.

9. Carolt TB. Penyakit Aterosklerotik koroner. In : Sylvia A. Price, Lorraine M. Wilson. Patofisiologi Konsep Klinis Proses-Proses Penyakit. Edisi 6. Jakarta: Penerbit buku kedokteran EGC; 2006.p.576-612

10. Soeharto I. Penyakit Jantung Koroner dan Serangan Jantung. Edisi kedua. Jakarta : PT Gramedia Pustaka Utama, 2004.p.51-5

11. Maryanto S, Fatimah-Muis Siti. Pengaruh Pemberian Jambu Biji (Psidium guajava L) pada Lipid Serum Tikus (Sprague Dawley) Hiperkolesterolemi. Media Medika Indonesiana 2004; 39 (2): 105-111.

12. Njoku V, Chidi O. Phytochemical constituents of some selected medicinal plants. O. Department of Chemistry, Imo State University, Owerri, Nigeria. Department of Pure and Industrial Chemistry, University of Port Harcourt, Port Harcourt, Nigeria. 2009; 3 (11): 228-233

13. Ernst J. Schaefer. High Density Lipoproteins, Dyslipidemia, and Coronary Heart Disease. Springer Sciene and Business Media, LLC 2010. Available from: URL: http://link.springer.com/book/10.1007/978-1-44191059-2/page/1

14. Qin Y, Xia M, Ma J, Hao Y, Liu J, Mou H, et al. Anthocyanin supplementation improves serum LDL and HDL cholesterol concentrations associated with the inhibition of cholesteryl ester transfer protein in dyslipidemic subjects. Am J Clin Nutr 2009;90:485-92.

15. Elfalleh W, Hannachi H, Tlili N, Yahia Y, Nasri N, Ferchichi A. Total phenolic contents and antioxidant activities of pomegranate peel, seed, leaf and flower. Departement de Biologie, Faculte des Sciences de Tunis, Universite de Tunis El 
Manar. Journal of Medical Plants Research 2012;6.pp.4724-4730.

16. Osman HF, Eshak MG, El-Sherbiny EM, Bayoumi MM. Biochemical and genetical evaluation of pomegranate impact on diabetes mellitus induced by alloxan in female rats. Radioisotopes Departement, Nuclear Research Center. Sci J 2012;9(3):1543-1553.

17. Ibrahium MI. Efficiency of pomegranate peel extract as antimicrobial, antioxidant and protection agents. Departement of Food Science and Technology, Faculty of Agriculture, Al-azhar University, Cairo, Egypt. 2010; 6(4):338-344.

18. Le D, Garcia A, Lohsoonthorn V, Williams MA. Prevalance and Risk Factors of Hypercholesterolemis among Thai Men and Women Receiving Health Examinations. Southeast Asian J Trop Med Public Health. 2006; Vol 37:No.5.

19. Xianli Wu, Beecher GR, Holden JM, Haytowitz DB, Gebhardt SE, Prior RL. Concentrations of Anthocyanins in Common Foods in the United States and Estimation of Normal Consumption. J. Agric. Food Chem. 2006; Vol 54: 4069-4075

20. Hardinsyah, Riyadi H, Niputupulu V. Kecukupan Energi, Protein, Lemak dan Karbohidrat. Jakarta. In press 2012.

21. High-Fiber Nutrition Therapy [editorial]. American Dietetic Association. Available from: URL:

http://www.bgsu.edu/downloads/sa/file81968.pdf

22. Executive Summary of the Third Report of the National Cholesterol Education Program (NCEP) Expert Panel on Detection, Evaluation, and Treatment of High Blood Cholesterol in Adults (Adults Treatment Panel III). [serial online]2002[cited 2013 May 2] Available from: URL:

http://www.nhlbi.nih.gov/guidelines/cholesterol/at p3full.pdf

23. Soeharto I. Pengaruh Usia dan Gender terhadap Kolesterol. Dalam : Serangan Jantung dan Stroke. Jakarta : PT Gramedia Pustaka Utama; 2004.p. 168-178.

24. Mann J, Stewart A.T. Essential of Human Nutrition Third Edition. USA : Oxford University. In press 2007.p.637.

25. Wiseman G. Nutrition \& Health. London: Taylor \& Francis. 2002.p.198

26. Kathleen MB, Mayes PA. Pengangkutan \& penyimpanan lipid. In: Murray RK, Granner DK, Mayes PA, Rodwell VW, editors. Biokimia Harper. Edisi Jakarta: Penerbit Buku Kedokteran EGC; 2009.p.225-38.

27. Samsukhidir SNAB. Determination of Antioxidant Activity And Nutrient Composition of Pomegranate Peel (Punica granatum). Food Science and technology In the Faculty of Applied Sciences, University Teknologi MARA, Malaysia;
2012. Available from: URL: http://eprints.uitm.edu.my/4997/1/SITI_NOR \%E F\%BF\%BD\%2580\%2598ADILAH_BINTI_SAM SUKHIDIR 12 24.pdf

28. Kane JP, Malloy MJ. Gangguan metabolisme lipoprotein. Dalam: Greenspan FS, Baxter JD, editor. Endokrinologi dasar dan klinik. Edisi 4. Alih bahasa: Wijaya C, Maulany RF, Samsudin S. Dalam: Kartini A, Mandera LI, Sadikin V, editor. Jakarta: EGC, 2000.p.847-56.

29. Brewer HB. Increasing HDL cholesterol levels. New Engl J Med. 2004.15.p.350.

30. Hatma RD. Lipid profiles among diverse ethnic groups in Indonesia. Department of Epidemiology, Faculty of Public Health, University of Indonesia, Depok. [2011, 43(1):4-11]

31. Kritchevsky D, Bonfield C, Anderson JW. Dietary Fiber; Chemistry, Physiology, and Health Effects. New York: Plenum Press; 1990.p.105-131.

32. Purwani NPR, Mulyati T. Pengaruh Pemberian Nata De Coco terhadap Kadar Kolesterol Total pada Wanita Hiperkolesterolemia. Jurnal of Nutrition College 2012; 1(1).p. 249-257.

33. Tzu-Li L, Hui-Hsuan L, Chang-Che C, MingCheng L, Ming-Chih C, Chau-Jong W, Hibiscus sabdariffa extract reduces serum cholesterol in men and women. Nutrition Research. 2007;27.p.140- 145 . 